УДК 343.31

DOI https://doi.org/10.15421/3919122

Чаплинська Ю. А.,

доктор юридичних наук, дочент,

професор кафедри кримінально-правових дисииплін

Дніпропетровського державного університету внутрішніх справ

\title{
ОСОБА ЗЛОЧИНЦЯ ЯК ЕЛЕМЕНТ КРИМІНАЛІСТИЧНОЇ ХАРАКТЕРИСТИКИ ЗЛОЧИНІВ
}

\section{THE IDENTITY OF THE OFFENDER AS AN ELEMENT OF THE FORENSIC CHARACTERISTIC OF THE CRIME}

\begin{abstract}
Наукова стаття присвячена висвітленню деяких аспектів розслідування злочинів. Розглядається особа злочинця як елемент криміналістичної характеристики. Вивчення особи злочинця надає слідчим низку додаткових можливостей. Особа злочинця як елемент криміналістичної характеристики - це сукупність соціально значущих ознак і відносин, які характеризують винну в порушенні кримінального закону людину, в поєднанні з іншими умовами та обставинами, що впливають на ії злочинну поведінку. Зокрема, відомості про неї надають змогу виокремити ті дані, що необхідні для організації найбільш ефективного розшуку особи, яка вчинила злочин, а в подальшому - iї викриття, забезпечують усунення причин й умов учинення злочинів та їх рецидивів. Під час проведення процесуальних дій - можливість ефективного встановлення психологічного контакту, застосування відповідних тактичних прийомів.

Для побудови дієвої криміналістичної характеристики повинні виокремлюватись елементи, які мають чітку розшукову спрямованість і можуть сприяти визначенню подальших напрямів розслідування. Тому беззаперечним $є$ виокремлення у структурі криміналістичної характеристики злочинів такої складової частини, як особа злочинця. Завдяки визначенню їі характерних ознак стає можливою побудова версій на початковому етапі розслідування, використання певних тактичних прийомів під час проведення процесуальних дій.

Криміналістичне вивчення особистості складається зі встановлення криміналістично значимої інформації про злочинця та інших учасників процесу розслідування. Дослідження особи злочинця як елементу криміналістичної характеристики надає змогу акумулювати в «портрет» ймовірного злочинця його характерні ознаки. Створення криміналістичного «портрету» 6 досить важливим для всього процесу розслідування. У будь-якому випадку, він надає змогу висунути певні версії та здійснювати розшук особи, що зникла з місця події, а також можливості якісного проведення подальших процесуальних дій.

Ключові слова: злочин, криміналістична характеристика, особа злочиния, мотив, слідчі (розшукові) дії.
\end{abstract}

The scientific article deals with some aspects of crime investigation. The identity of the offender is considered as an element of forensic characteristics. Investigating the identity of the offender provides the investigation with a number of additional features. The identity of the offender as an element of forensic characteristics is a set of socially significant features and attitudes that characterize a person guilty of violating the criminal law, in combination with other conditions and circumstances affecting his criminal behavior. In particular, the information about it allows to distinguish the data necessary for the organization of the most effective search of the person who committed the crime, and subsequently - its exposition, provide elimination of the causes and conditions of committing criminal offenses and their recidivism. And during the conduct of investigative (search) actions - the possibility of effective establishment of psychological contact, the use of appropriate tactical techniques.

In order to construct an effective forensic characteristic, elements must be identified that have a clear investigative focus and can help determine further directions of the investigation. Therefore, it is indisputable to distinguish in the structure of forensic characteristics of crimes such component as the person of the offender. By identifying its characteristic features, it becomes possible to build versions at the initial stage of the investigation, to use certain tactical techniques in the course of procedural actions.

A forensic investigation of an individual consists of establishing forensically relevant information about the offender and other participants in the investigation process. Investigation of the identity of the offender as an element of forensic characteristics, allows to accumulate in the portrait of the likely offender his characteristic features. Creating a forensic portrait is important enough for the whole investigation process. In any case, it allows you to put forward certain versions and search for the person who disappeared from the scene, as well as the possibility of qualitative procedural actions.

Key words: crime, criminalistics characteristics, identity of the offender, motive, investigative (search) actions.

Постановка проблеми. У ході кримінального провадження значна частина діяльності працівників правоохоронних органів та суду спрямована на встановлення особи, яка вчинила суспільно-небезпечне діяння, а також спілкування та проведення ряду слідчих (розшукових) і процесуальних дій, відповідно, 3 підозрюваним, обвинуваченим, підсудним. Тому зрозуміло, що особа злочинця займає значне місце в системі будь-якої характеристики злочину: кримінально-правової, кримінологічної i, звичайно, криміналістичної.

Із криміналістичної точки зору вивчення особи злочинця надає слідству ряд додаткових можливос- тей. Зокрема, відомості про неї дають змогу виокремити ті дані, що необхідні для організації найбільш ефективного розшуку особи, яка вчинила злочин, а в подальшому - iї викриття, забезпечують усунення причин та умов вчинення кримінальних правопорушень та їх рецидивів. А під час проведення слідчих (розшукових) дій - можливість ефективного встановлення психологічного контакту, застосування відповідних тактичних прийомів.

Аналіз публікацій, в яких започатковано розв'язання даної проблеми. Особу злочинця розглядали у своїх працях такі науковці, як В.П. Бахін, Р.С. Бєлкін, А.Ф. Волобуєв, А.В. Іщенко, О.В. Кузь- 
менко, В.К. Лисиченко, В.Г. Лукашевич, М.І. Порубов, М.В. Салтевський, К.О. Чаплинський, В.Ю. Шепітько, М.П. Яблоков та інші. Потрібно зазначити, що наше дослідження $є$ комплексним підходом до вивчення зазначеної категорії через призму вивчення різних думок науковців та емпіричного матеріалу.

Метою даної статті $\epsilon$ дослідження особи злочинця як елементу криміналістичної характеристики злочинів.

Виклад основного матеріалу. Ряд вчених-криміналістів вважають за необхідність вивчати особу злочинця. Деякі з них визначають об'єктивну необхідність застосовування відомостей про дану категорію не тільки у криміналістичної тактиці, але й у методиці розслідування злочинів $[12$, с. 53]. Інші розглядають необхідність дослідження особи злочинця лише для вирішення завдань, що виникають перед криміналістичною тактикою [6, с. 7]. У будь-якому випадку, не виникає сумніву в тому, що вивчення зазначеного питання як криміналістичної категорії $\epsilon$ важливим аспектом для розслідування кожного окремо взятого кримінального правопорушення.

Тому особа злочинця потребує поглибленого дослідження. Адже особистість злочинця, як доречно відмічає А.Ф. Зелінський, є наріжним каменем кримінальної психології, бо людина, яка порушила кримінальний закон, $\epsilon$ автором злочину, а іiі «справа» перетворює громадянина на злочинця, який відкидається суспільною свідомістю [4, с. 9].

Розвиток уявлень про визначення поняття особи злочинця, а також його наповнення змінювався протягом не одного століття. До ХХ ст. погляди на особу злочинця, про що доречно наголошує С.А. Шалгунова, були різноманітними. На ранніх етапах розвитку суспільства дослідники пояснювали причини вчинення злочинних діянь впливом на особу чогось божественного або диявольського, впливом психічних відхилень та соціуму [16, с. 163]. Зараз також існують різні визначення цієї категорії.

Зокрема, деякі автори розглядають це поняття як сукупність соціально значущих ознак, зв'язків і відносин, які характеризують людину, винну в порушенні норм кримінального закону $[8$, с. 72$]$. У свою чергу, I.M. Даньшин визначає особу злочинця як сукупність істотних і стійких соціальних властивостей і ознак, соціально значущих біопсихологічних особливостей індивіда, які, об'єктивно реалізуючись у конкретному вчиненому злочині, надають вчиненому діянню характер суспільної небезпечності, а винній у цьому особі - властивості суспільної небезпечності, у зв'язку із чим вона і притягається до відповідальності, передбаченої кримінальним законом [7, с. 65].

В.Г. Лукашевич та М.В. Салтевський визначили іiі як соціально-біологічну систему, властивості (фізичні, біологічні та соціальні) якої відображаються в матеріальному середовищі та використовуються для розслідування злочинів [13, с. 112]. А вже М.М. Демідов через призму криміналістичної характеристики визначає іï як стійку криміналістично значиму сукупність психофізичних властивостей і якостей, мотиваційних установок, емоційної і раціональної сфер людської свідомості, що відобразились у слідах злочину в процесі підготовки, вчинення і приховання слідів злочину, а також поведінки після вчинення злочину [3, с. 16].

Погоджуючись із наведеними поняттям, вкажемо, що особа злочинця як елемент криміналістичної характеристики - це сукупність соціально значущих ознак і відносин, які характеризують винну в порушенні кримінального закону людину в поєднанні з іншими умовами та обставинами, що впливають на iï злочинну поведінку.

Для криміналістичного вчення про особу злочинця важливе значення має визначення ії структури. До неї Ф.В. Глазирін пропонує віднести соціально-демографічні властивості, психологічні якості, біологічні особливості особи [2, с. 6]. Інші автори по-своєму визначають іiі наповнення: демографічні дані; дані, що характеризують суспільне місце обвинуваченого; відомості про умови життя обвинуваченого; відомості про стан здоров'я обвинуваченого; характер і темперамент [5, с. 16]. Утім, на нашу думку, найбільш чітко визначив структуру особи злочинця В.Ю. Шепітько: дані демографічного характеру, моральні якості та психологічні особливості $[17$, c. 258].

Підводячи підсумок, зазначимо, що відомості про особу, що вчинила злочин, будемо розглядати відносно наступної структури: 1) соціально-демографічні; 2) моральні якості; 3) психологічні властивості.

Соціально-демографічні ознаки властиві будьякій особі. Тi, що мають криміналістичне значення, на наш погляд, виглядають таким чином: відомості про стать, вік, освіту, сімейний стан, рід занять, місце проживання, наявність попередньої судимості, належність до певної соціальної групи та інші відомості демографічного характеру. Відповідно до зазначених характеристик i було проведене наше дослідження.

Відношення місця проживання до місця вчинення кримінального правопорушення має значення для працівників правоохоронних органів у різних аспектах. Зокрема, для висунення версії щодо місцеперебування зловмисника, подальших слідчих (розшукових) дій тощо.

Підводячи підсумок із приводу соціально-демографічних ознак, слід зазначити, що вони дають істотну інформацію про особу злочинця. Вона може бути використана як у науці, так i в практичній діяльності, зокрема під час розроблення та реалізації заходів профілактики кримінальних правопорушень, розроблення версій, підготовки та безпосереднього проведення слідчих (розшукових) дій. Поведінка людини багато в чому залежить від іï статусу в суспільстві, тому соціальні прояви є необхідними для вивчення особистості злочинця. Соціально-демографічні ознаки містять інформацію, без якої неможлива повна криміналістична характеристика особи.

Другу групу, яку ми будемо розглядати, становлять моральні якості злочинця. Як і будь-яка людська особистість, особа злочинця, на думку А.Б. Сахаро- 
ва, включає в себе певну систему моральних властивостей - поглядів і переконань, потреб та інтересів, життєвих цілей та очікувань, інтелектуальних, емоційних і вольових особливостей [14, с. 89]. Відповідно до моральних якостей людини Е. Феррі розрізняв такі типи злочинців: 1) природжені; 2) «злочинці внаслідок безумства» - психопати та особи, які страждають психічними аномаліями; 3) злочинці через пристрасть; 4) випадкові; 5) звичні [15, с. 31].

Моральність і психологія особистості формує потреби, інтереси та, нарешті, мотивацію, що й породжують злочинну поведінку [11, с. 104]. Серед моральних властивостей особи злочинця слід виділити такі: правові, трудові, сімейно-побутові, міжособистісні, самооцінка («самосвідомість»). Вади правових властивостей виражаються у злочинній поведінці та ставленні до вчиненого, до правових цінностей - закону, правозастосування та ін. Через специфіку об'єкта посягання важко окреслити єдиний морально-психологічний портрет особи злочинця.

По-перше, для моральних ознак злочинців характерне зневажливе ставлення до нормального фізіологічного та морального розвитку дитини, а також загальноприйнятих правил поведінки. По-друге, переважна факт корисливого мотиву. По-третє, ідеали сім’ї у таких осіб або занижені, або відсутні.

Другу групу, яку ми будемо розглядати, становлять психологічні якості злочинця. У структурі особи злочинця Г.А. Аванесов виділяє психологічну (індивідуальність) складову частину. Вона, на думку автора, будується за рівнями, де до нижчого належать біологічно зумовлені природні властивості та особливості, а найвищий рівень утворює спрямованість особи. У свою чергу, в загальній структурі особи можна лише умовно виокремити кримінологічний рівень, де увагу слід зосереджувати на антисуспільній спрямованості особи та особистій установці злочинця. За такого підходу, зазначає Г.А. Аванесов, кримінологами у структурі особи злочинця виокремлюються три основні групи ознак: а) загальні ознаки особи; б) 3-4 особливі ознаки особи злочинця; 3) ознаки особи конкретного суб'єкта, який вчинив злочин, що індивідуалізують його як особу злочинця [9, с. 264].

Є вартою для розгляду класифікація особистостей, запропонована психологом А.Ф. Лазурським, а конкретно - збочені типи особистості нижчого рівня. До них науковець відносив такі: 1) пасивний тип, який виступає у вигляді двох різновидів: а) апатичний, що характеризується байдуже-млявим ставленням до всього оточуючого, відсутністю яскраво виражених інтересів і потреб; б) безвольно-боязкий, якого легко переконати, з переважанням пригніченого настрою. На думку вченого, люди такого типу, хоча і не відносяться до кримінального типу, можуть бути джерелом поповнення злочинного світу; 2) тип розважливого егоїста. Люди цього типу розважливі і хитрі, черстві і злопам'ятні; на першому плані в них - турбота про свої вигоди і інтереси, переважно матеріальні; цей тип дуже близький до кримінального; 3) афектно-збочений тип. Його представники - безладно веселі, легковажні люди. За своїм соціальними проявами - п’яниці, забіяки, скандалісти, дрібні злодюжки; 4) активно-збочений тип (гвалтівник). Тут два підтипи: а) безладного гвалтівника, який характеризується рішучістю, енергією. Працювати не любить, схильний до бійок; б) зосереджено-жорстокий, який не зупиняється i перед вбивством [10, с. 64].

Загалом, психологічна характеристика особи злочинця, як відмічає В.Л. Васильєв, полягає у системі ряду ознак: мотиви поведінки, загальна структура та окрема риси характеру, здібності, емоційно-вольова сфера, індивідуальна особливості інтелектуальної діяльності, пам'яті та інших пізнавальних процесів $[1$, c. 330$]$. Для злочинців, що вчинюють свої діяння умисно, характерними психологічними особливостями будуть егоцентризм, жорстокість, агресивність, цинізм, схильність до асоціативних форм тощо.

Висновок. Підводячи підсумок у розгляді особи злочинця як елемента криміналістичної характеристики, наведені дані спробуємо акумулювати в «портрет» ймовірного злочинця, який вчинює злочинні діяння. Особа злочинця як елемент криміналістичної характеристики - це сукупність соціально значущих ознак і відносин, які характеризують винну в порушенні кримінального закону людину, в поєднанні з іншими умовами та обставинами, що впливають на ii злочинну поведінку. Створення криміналістичного «портрету» $\epsilon$ досить важливим для всього процесу розслідування. У будь-якому випадку, він надає змогу висунути певні версії та здійснювати розшук особи, що зникла з місця події, а також можливості якісного проведення подальших слідчих (розшукових) дій.

\section{ЛІТЕРАТУРА:}

1. Васильев В.Л. Юридическая психология : учебник для вузов. Санкт-Петербург : Питер, 2008. 665 с.

2. Глазирин Ф.В. Изучение личности обвиняемого и тактика следственных действий. Свердловск, 1973.156 с.

3. Демидов Н.Н. Изучение личности преступника в процессе расследования : дисс. ... к. ю. н. Волгоград, 2003. 187 с.

4. Зелинский А.Ф. Криминальная психология. Київ : Юринком Интер, 1999. С. 9.

5. Коршик М.Г. Изучение личности обвиняемого на предварительном следствии. Москва : Юрид. лит-ра, 1969. 20 с.

6. Кривошеев А.С. Изучение личности обвиняемого в процессе расследования. Москва, 1971.

7. Кримінологія : Загальна та особлива частини : підруч. для студ. юрид. спец. вищ. навч. закл. / І.М. Даньшин, В.В. Голіна, О.Г. Кальман, О.В. Лисодєд ; за заг. ред. І.М. Даньшина. Харків : Право, 2003.

8. Кримінологія : підруч. для студ. вищ. навч. закл. / О.М. Джужа, Я.Ю. Кондратьєв, О.Г. Кулик та ін. ; за заг. ред. О.М. Джужи. Київ : Юрінком Інтер, 2002.

9. Криминология : учеб. / под ред. Г.А. Аванесова. 3-е изд., перераб. и доп. Москва : ЮНИТИ-ДАНА, 2005.480 с.

10. Лазурский А.Ф. Классификация личностей. Петербург, 1921. С. 63-65.

11. Михайлов О.С. Кримінологія : навч. посіб. Київ : Знання, 2012. 565 с.

12. Ратинов А.Р. Советская психология как наука. Советское государство и право. 1965. № 5. С. 53-54. 
13. Салтевський М. В. Навчально-довідковий посібник з криміналістики. Київ : ВІПОЛ, 1994. 180 с.

14. Сахаров А.Б. Проблема преступности в современных условиях. Ереван : Айастан, 1991. 278 с.

15. Фэрри Э. Уголовная антропология и социализм. Проблемы преступности. 1924. Сб. 2. С. 31-32.

16. Шалгунова С.А. Особа злочинця за уявленнями дореволюційних вітчизняних юристів: антропологічна та соціологічна школи. Право і суспільство. 2011. № 6. С. 157-164.

17. Шепитько В.Ю. Криминалистика : Курс лекций. Издание второе, переработанное и дополненное. Харьков : ООО «Одиссей», 2005. 368 с. 